\title{
Sustainable effects of diatomite on the growth criteria and phytochemical contents of Vicia faba plants.
}

\author{
Mona M. Abdalla* \\ Department of Botany, Faculty of Science, Ain Shams University, Cairo, Egypt.
}

\begin{abstract}
Recent scientific findings proved that silicon feeding will provide benefits to plant growth and yield depending on the source of $\mathrm{Si}$, the mode of application , the concentration used, the plant species, the mode of action and the biotic or abiotic factor involved. To better understand the intrinsic properties of $\mathrm{Si}$, this work was conducted using a series of diatomite (diatomaceous earth)at rates of $0,2.5,5$ and $10 \mathrm{~g} / \mathrm{kg}$ soil, to look into the most subtle changes in the growth , yield, metabolism, electropharetic protein and isozyme pattern of faba bean ( Vicia faba) plant. Indeed, diatomite-treated plants displayed an over all better morphological increments expressed as shoot and root length , number of leaves and pods/ plant, fresh and dry weights of shoots and roots and physiological activity expressed as chlorophyll a,b and total pigments, total soluble sugars (TSS) and total sugars (TS), photosynthetic rate, leaf stomatal conductance, \% of leaf relative humidity $(\% \mathrm{LRH})$, net intercellular carbon dioxide $\left(\Delta \mathrm{CO}_{2}\right)$, total nitrogen $(\mathrm{TN})$ and total soluble nitrogen (TSN) and the concentrations of phosphorus $(\mathrm{P})$, potassium $(\mathrm{K})$, calcium $(\mathrm{Ca})$ and magnesium $(\mathrm{Mg})$ than non-treated faba bean plants . Furthermore, diatomites $\left(86-89 \% \mathrm{SiO}_{2}\right)$ induced and restored ten electrophoretic protein bands which confirmed their significance as an algal manure in accelarating the gene functions to perform, in an elevated rate, new silence genes to operate thus expressing new protein profiles. Soil fertilization by diatomites induced four esterase ( EST), three peroxidase (POD), two catalase (CAT) and three acid phosphatase (ACP) isozyme polymorphic bands which were absent in the control plants .The intensity and density of these bands were significantly increased in response to diatomite treatment. The impact of diatomite is time-dependent as it became more effective while the experiment continued and increased in a dose-related manner. Reversibly, diatomites application showed negative response in the transpiration rate and the values of both carotenoids, sodium and iron. This study highlighted the fact that diatomites are important component of the production system and should not be ignored when attempting to attribute causes for below optimum production
\end{abstract}

Keywords: Diatomites; total soluble sugars; total sugars; gas exchange measurements; leaf relative humidity ; total nitrogen; mineral element concentrations; protein electrophoresis ; isozyme electrophoresis.

\section{INTRODUCTION}

There is an expressed doctrine that plants need 16 essential elements to grow. In reality, however, plant growth requires far more than 16 elements (Chen et al, 2000). Silicon (Si) is one of the elements not included in this list but quantitatively proven to be a major inorganic constituent of plants. Si is the second most abundant element on the surface of the earth and accounts for up to 41 percent of the earth's crust and in the soils.It is most commonly found in soil solution as silicic acid, $\mathrm{H}_{4} \mathrm{Si}_{4}$, which is readily absorbed by plants (Epstein, 1999). Tissue analysis from a wide variety of plants found Si concentrations in those plants to range form 0.2 to 10 percent of dry weights, depending on plant species( Chen et al ,
2000). This concentration range is equivalent to those of $\mathrm{Ca}, \mathrm{Mg}, \mathrm{P}$ and $\mathrm{S}$, four of the essential elements (Chen et al , 2000; Liang et al, 2007). Despite the prominence of Si within a plant's physical make up, Si has not been considered as an essential element and has not been included in any standard formulation of nutrient solutions and feritlizers (Chen et al , 2000; Liang et al. 2007). Expressly, Si supplements have been widely used in China, Japan and Korea in rice and sugar cane production and in Europe for the production of greenhouse crops (Epstein, 1999; Savant et al 1997; Matichenkov and Calvert, 2002; Matichenkov , 2004). Subsequently, Si is now considered by some growers and researchers 
as a quasi- essential element for plant growth and development. (Chen et al, 2000 Liang et al, 2007).

Fortunately, Diatomite's de Mozambique (DDM), produced a natural completely safe product of finest quality suitable for use as soil fertilizer and enhancer, animal feed additive, inseticide and inferring resistance to plants under both biotic and abiotic stresses. Diatomite is a sedimentary rock primarily composed of fossilized remains of microscopic unicellular algae, namely diatoms, with cell well impregnated with silica (as $\mathrm{SiO}$ ). It contains a high amount of water soluble silica (120ppm vs $10 \mathrm{ppm}$ of normal soil) available to plants (Kruger, 2006). Diatomite, being mostly chemically composed of $\mathrm{SiO}_{2}$ $(86-89 \%)$ and small amount of trace elements, it is considered as a complete fertilizer. Moreover, it has a multi- functional purpose as it improves the physical structure of soil by breaking up heavy based soil and retaining moisture in light or sandy soil for longer period (absorb up to $200 \%$ of its weight in water) without interfering with soil chemistry nor breaking down or decomposing like other growing medium. It also increases crop production and quality and help restore heavy metals and hydrocarbon polluted areas. As a natural insecticide, it kills insects physically by removing the epicuticlar- lipid layer of insects resulting an excessive water loss through the cuticle and eventually death by desiccation. Because this action is physical, insects cannot build up resistance to diatomite. DDm diatomite has been internationally ecocerted at March, 2006 (Kruger, 2006). Si has been generally recognized to have a beneficial role in stimulating the various forms of growth and the biochemical contents of many plant species. Concerning growth responses, this element was found to enhance stem elongation and strength (Matichenkov and Kosobrukhov, 2004; Hull, 2004); stimulates root elongation, restores root growth and ameliorates root growth inhibition caused by either toxic heavy metals as $\mathrm{Al}$ and $\mathrm{Mn}$ or water and salt stresses (Matichenkov and Kosobrukhov, 2004), enhances shoot/root ratio and restores it (Galvez et al, 1987), increases the number of leaves ,number of tillers and panicles in rice (Liang et al, 1994), increases the seedling biomass and made them healthy and strong (Savant and Sawant, 1995), stimulates both the shoot and root dry weights of various plant species (Liang et al ,2007 ) and eventually has a remarkable positive effect during the reproductive growth stage of many crop plants which includes the number of spikelets / panicles, grainfilling, grain ripening, yield percentage and quality (Matichenkov and Calvert, 2002). At the biochemical level, Si application to various tested plants increases the content of photosynthetic pigment and chlorophyll whereas its deficiency causes the yellowing or browning of lower leaves and their necrosis (Savant et al, 1997; Gong et al, 2005; Nwugo and Huerta, 2008), it promotes photosynthetic rates through increasing both the photochemical efficiency of PSII, the stomatal conductance and the net assimilation rate of $\mathrm{CO}_{2}$ (Savant et al, 1997; Matichenkov and Kosobrukhov, 2004), Gong et al, 2005; Nwugo and Huerta, 2008 ), this therefore improves the supply and the content of carbohydrates in treated plants (Matichenkov and Calvert, 2002 ). Moreover, Si depresses excessive transpiration and water loss from plants which increases their water use efficiency (WUE) and thereby preventing leaf water stress and keeps them erect thus improving their light use efficiency and eventually their photosynthetic rate (Hull, 2004; Nwugo and Huerta, 2008). In addition, Si application has been reported to decrease the uptake of iron, nitrogen and potassium but increases the uptake of phosphorus, calcium, magnesium and the formation of carbohydrates in transplanted rice (Islam and Soha, 1969 ), to enhance K:Na selectivity ratio with concomitant decline in $\mathrm{Na}$ adsorption by plants(Matichenkov et al, 2001;Liang et al ,2007) and to reduce electrolyte leakage percentage thus increasing the element content of tissues (Zhu et al ,2004 ; Nwugo and Huerta, 2008). Recent work have shown that silicon increased the protein content of either drought or salt- stressed plants by either increasing protein biosynthesis or decreasing its oxidation which is accomplished by an increase in the activities of certian antioxidant and hydrolytic enzymes as peroxidases (POD), catalases (CAT) , esterases (EST), and acid phosphatases (ACP)(Aleshin, 1988; Zhu et al, 2004 Gong et al, 2005).

Furthermore, a gene responsible for xylem loading of $\mathrm{Si}$ has recently been mapped to chromosome 2 of rice using Lsi1 mutant and is localized on the plasma membrane of the distal side of both exodermis and endodrmis cells and constitutively expressed in the roots. it is predicted to encode a membrane protein similar to water channel proteins (aquaporins) ( $\mathrm{Ma}$ et al, 2006). The objective of this work was to investigate the impact of diatomites on the growth criteria , the metabolic contents of Vicia faba plants , the exact dose that induces optimum growth rate and to throw light on the possible mechanism of action of this fossilized natural product on the growth and development of faba bean plants . 


\section{MATERIAL AND METHODS}

Plant material and treatments: Seeds of Vicia faba c.v. Giza 402 were obtained from the Agricultural Research Centre, Giza, Egypt. The seeds were sterilized with sodium hypochlorite $5 \%$ for $5 \mathrm{~min}$, then washed thoroughly with distilled water .They were then soaked for $6 \mathrm{hr}$ at $18^{\circ} \mathrm{C}$ in distilled water. Afterwards, they were sown in 40 plastic pots $(20 \mathrm{~cm}$ in diameter and $19 \mathrm{~cm}$ in depth) containing 2.5 $\mathrm{kg}$ of graden soil per pot which were evenly mixed with different concentrations $(0,2.5,5$ and $10 \mathrm{~g} / \mathrm{kg}$ soil ) of DDM diatomite.Its a natural diatomaceous earth originated from fossilized remains of fresh water diatoms with cell well impregnated with silica.It is $\mathrm{pH}$ neutral and composed mainly of $\mathrm{SiO} 2(86-89 \%)$ in a soluble form beneficial to plants (Table1).

Table 1: Major chemical elements

\begin{tabular}{|l|l|}
\hline $\mathrm{SiO}_{2}$ & $89.00 \%$ \\
\hline $\mathrm{Al}_{2} \mathrm{O}_{3}$ & $5.95 \%$ \\
\hline $\mathrm{Fe}_{2} \mathrm{O}_{3}$ & $0.88 \%$ \\
\hline $\mathrm{CaO}$ & $0.10 \%$ \\
\hline $\mathrm{K} 2 \mathrm{O}$ & $0.63 \%$ \\
\hline $\mathrm{MgO}$ & $0.20 \%$ \\
\hline $\mathrm{Na}_{2} \mathrm{O}$ & $0.32 \%$ \\
\hline $\mathrm{TiO}_{2}$ & $0.29 \%$ \\
\hline $\mathrm{H}_{2} \mathrm{O}$ & $<3 \%$ \\
\hline
\end{tabular}

Eight seeds were sown in each pot and ten pots were specified for each concentration. The experiment was conducted in greenhouse and maintained under constant climatic conditions (day/night temperature, $22 / 10^{\circ} \mathrm{C} \pm 2$; relative humidity, $60-65 \%$; $11 \mathrm{~h}$ day length). During flowering (6 weeks) and pod-filling (10 weeks) 10 plants from each treatment were randomly selected for the measurement of growth criteria, photosynthetic and transpiration rates, stomatal conductance, net intercellular $\mathrm{CO}_{2}$, photosynthetic pigments and percentage of relative humidity (\%LRH). In the mean time, samples were taken (5replictes for each treatment ) and either over-dried for carbohydrate, nitrogen and mineral element determinations or rapidly frozen for either pigment , total protein and isozyme electrophoresis.

Measurements of gas exchange and relative humidity: Photosynthesis and transpiration rates, stomatal conductance, net intercellular $\mathrm{CO}_{2}\left(\Delta \mathrm{CO}_{2}\right)$ and percentage of leaf relative humidity of leaves $(\% \mathrm{LRH})$ were measured using an open gas portable photosynthesis system( $\mathrm{Li} \quad-6400 . \mathrm{LI}-\mathrm{COR}$,Bio Sciences, U.S.A ). Measurements were performed on sunny days under natural light conditions between 9.00h and $12.00 \mathrm{~h}$ on the uppermost fully expanded leaves of 10 plants randomly chosen per treatment and expressed on a leaf area basis. the relative humidity was $50 \%$ and the temperature was $22^{\circ} \mathrm{C}$ (Renault et al, 2001).

Chemical analysis: Photosynthetic pigments(chl.a, chl.b and carotenoids) were determined specrophotometrically (Metzner et al, 1965) carbohydrate fractions were extracted, clarified and determined as total soluble sugars (TSS) and total sugars (TS) (Dubois et al, 1965). Total $-\mathrm{N}$ and total soluble- $\mathrm{N}$ were determind by micro- kjeldahl, tector model 1026 after digestion in sulphuric acid (Horwilz, 2002). Mineral elements were extracted from tissues similar to that of Chapman and Pratt (1961).Phosphorus was determind following the method described by Humphries (1956). Sodium and potassium were estimated photometrically according to Williams and Twine (1960). Calcium, magnesium and iron were determined by atomic absorption spectrophotometer according to A.O.A.C(1984).

Electrophoretic analysis of total protein and isozymes: Electrophoretic analysis of total protein was performed to study the gene expression of genotypes after treatment with DDM diatomites. It was performed according to Laemmli (1970)using sodium dodecyl sulphate polyacrylamide gel electrophoresis ( SDS-PAGE) staining of gel with silver nitrate was according to the method of Goldberg and Warner (1997)and then scanning them using Gel Doc 2000 system followed by analyzation with software supplied by the manufacturer. The isoyme electro phoretic patterns for peroxidase ( POD) esterase (EST), catalase (CAT) and acid phosphatase (ACP)were extracted with $1.5 \mathrm{ml}$ extraction buffer (pH8.9). samples were centrifuged for 10 minutes at $10,000 \mathrm{rpm}$ at $4^{\circ} \mathrm{C}$. Polyacrylamide gel electrophoresis (PAGE)was performed according to Stegemann (1979). Gel preparation and enzyme staining solution were performed according to Wendel and Weeden (1989).

Morphologic and metabolic data were statistically analyzed using the one- way analysis of variance (ANOVA) to test for effects among treatment, followed by Duncan's multiple range test to compare means between the different treatment. Moreover,standard deviation (SD) levels have been measured for five replicates of each result of the metabolic analysis. 


\section{RESULTS AND DISCUSSION}

Growth responses: At age of 6 weeks, plants treated with the highest concentration of diatomite $(10 \mathrm{~g} / \mathrm{kg}$ soil) displayed the highest growth rates expressed as shoot and root length, fresh and dry weight of shoots and roots and number of leaves above the control plants, while at the next age (10weeks) the medium concentration $(5 \mathrm{~g} / \mathrm{kg}$ ) induced the maximum growth rates (table2). These results coincided with those of other workers using several examined plants. for instance, $\mathrm{Si}$ promoted the number of tillers, number of panicles, number of spikelets / panicles, grain filling, grain yield and quality of rice (Savant et al, 1997 and), stem strength in turfgrasses (Hull, 2004), the height of both roots and coleoptiles of wheat and barley (Matichenkov and Kosobrukhov, 2004), the fresh and dry weights of both shoots, roots in squash and maize (Liang et al, 2007; Savvas et al, 2009)and eventually the no. of fruits /plant thus increasing agricultural productivity (Savvas et al, 2009) Thus, Si exerts its beneficial effects on the growth of plants via the improvement of nutrient uptake and balance in plants, reduction of mineral toxicity, enhancement of photosynthetic activity and increasing resistance to biotic stresses(Hull,2004; Matichenkov and Kosobrukhov, 2004; Liang et al., 2007).

Table 2. Changes in the growth criteria of Vicia faba plants in response to diatomite treatment . Each value is a mean of ten replicates.

\begin{tabular}{|c|c|c|c|c|c|c|c|c|c|}
\hline Age/week & $\begin{array}{c}\text { Concentrati } \\
\text { on } \\
\text { glkg }\end{array}$ & $\begin{array}{c}\text { Shoot } \\
\text { length } \\
\text { (cm) }\end{array}$ & $\begin{array}{c}\text { Root } \\
\text { length } \\
\text { (cm) }\end{array}$ & $\begin{array}{c}\text { No. of } \\
\text { leaves }\end{array}$ & $\begin{array}{c}\text { Fresh wt. } \\
\text { of } \\
\text { shoot(g) }\end{array}$ & $\begin{array}{c}\text { Fresh } \\
\text { wt. Of } \\
\text { root(g) }\end{array}$ & $\begin{array}{c}\text { Dry wt. } \\
\text { Of } \\
\text { shoot(g) }\end{array}$ & $\begin{array}{c}\text { Dry } \\
\text { wt. Of } \\
\text { root(g) }\end{array}$ & $\begin{array}{c}\text { No.of } \\
\text { pods/ } \\
\text { plant }\end{array}$ \\
\hline \multirow{3}{*}{6} & 0 & $24.5 \mathrm{~d}$ & $17.62 \mathrm{c}$ & $13.9 \mathrm{~d}$ & $10.44 \mathrm{c}$ & $3.98 \mathrm{c}$ & $1.16 \mathrm{~d}$ & $0.47 \mathrm{~cd}$ & - \\
\cline { 2 - 10 } & 2.5 & $31.1 \mathrm{c}$ & $19.15 \mathrm{~b}$ & $15.3 \mathrm{c}$ & $14.01 \mathrm{bc}$ & $5.12 \mathrm{~b}$ & $1.23 \mathrm{c}$ & $0.50 \mathrm{c}$ & - \\
\cline { 2 - 10 } & 5.0 & $39.2 \mathrm{~b}$ & $20.84 \mathrm{ab}$ & $16.8 \mathrm{~b}$ & $15.08 \mathrm{~b}$ & $6.55 \mathrm{a}$ & $1.50 \mathrm{~b}$ & $0.63 \mathrm{~b}$ & - \\
\cline { 2 - 10 } & 10 & $\mathbf{4 5 . 0 \mathrm { a }}$ & $21.51 \mathrm{a}$ & $19.4 \mathrm{a}$ & $16.61 \mathrm{a}$ & $6.93 \mathrm{a}$ & $1.84 \mathrm{a}$ & $0.72 \mathrm{a}$ & - \\
\hline \multirow{3}{*}{10} & 0 & $35.7 \mathrm{c}$ & $19.0 \mathrm{c}$ & $18.3 \mathrm{c}$ & $15.72 \mathrm{~d}$ & $5.16 \mathrm{~b}$ & $1.68 \mathrm{~b}$ & $0.56 \mathrm{~d}$ & $5.0 \mathrm{~d}$ \\
\hline & 2.5 & $42.6 \mathrm{~b}$ & $21.46 \mathrm{bc}$ & $20.1 \mathrm{bc}$ & $17.61 \mathrm{c}$ & $6.84 \mathrm{ab}$ & $1.96 \mathrm{~b}$ & $0.61 \mathrm{c}$ & $7.8 \mathrm{c}$ \\
\cline { 2 - 10 } & 5.0 & $51.8 \mathrm{a}$ & $22.51 \mathrm{~b}$ & $23.4 \mathrm{a}$ & $21.07 \mathrm{a}$ & $7.38 \mathrm{a}$ & $2.69 \mathrm{a}$ & $0.81 \mathrm{a}$ & $10.9 \mathrm{a}$ \\
\cline { 2 - 10 } & 10 & $49.3 \mathrm{ab}$ & $24.82 \mathrm{a}$ & $21.2 \mathrm{~b}$ & $18.82 \mathrm{~b}$ & $7.09 \mathrm{a}$ & $2.34 \mathrm{a}$ & $0.70 \mathrm{~b}$ & $9.8 \mathrm{~b}$ \\
\hline
\end{tabular}

Photosynthetic pigments, total sugars and total soluble sugar concentrations: DDM diatomite at all rates applied and at both ages of growth of faba beans (6\&10weeks) obviously raised the amounts of chlorophyll a, b, total pigments, total soluble sugars and total sugars while it depressed those of carotenoids above and below those of untreated plants respectively . Such increases or decreases were more pronounced at the highest rate of diatomite $(10 \mathrm{~g} / \mathrm{kg}$ soil $)$ at age 6 weeks while it was pronounced at the medium rate $(5 \mathrm{~g} / \mathrm{kg}$ soil $)$ at the next age (table3). These results are confirmed by comparable works using $\mathrm{Si}$ which influence the chlorophyll content \& chlorophyll fluorescence in various plants (Gong et al , 2005 ) and the levels of total sugars, soluble sugars, sucrose and raffinose (Matichenkov and Calvert, 2002). It was suggested that the main role of $\mathrm{Si}$ in increasing the chlorophyll levels arises from its maintenance of the chloroplast ultrastructure concomitant with the enhancement of chlorophyll biosynthetic enzymes and /or depression of chlorophyll- degrading enzymes (Liang et al ,2007; Savvas et al , 2009). The synergistic effect of Si on photosynthesis and chlorophyll content improved markedly the carbohydrate biosynthesis, the supply of cell well material e.g. cell wall polysaccharides and lignin polymers and eventually the dry matter production (Savant et al, 1997; Rodrigues et al, 2005). 
Table 3. Changes in the photosynthetic pigment contents of Vicia faba plants in response to diatomite treatment. Each value is a mean of 5 replicates and expressed as mglg.f.wt.(photosynthetic pigment) or mg/g.d.wt. (sugars).

\begin{tabular}{|c|c|l|l|l|l|l|l|}
\hline Age/week & $\begin{array}{c}\text { Concentrati } \\
\text { on }(\mathrm{g} / \mathrm{kg})\end{array}$ & Chlorophyll (a) & Chlorophyll (b) & Carotenoids & $\begin{array}{l}\text { Total } \\
\text { Pigments }\end{array}$ & $\begin{array}{l}\text { Total soluble } \\
\text { sugars } \\
\mathrm{mg} / \mathrm{g} . \mathrm{d} . \mathrm{wt}\end{array}$ & $\begin{array}{l}\text { Total sugars } \\
\mathrm{mg} / \mathrm{g} . \mathrm{d} . \mathrm{wt}\end{array}$ \\
\hline \multirow{3}{*}{6} & 0 & $4.36 \mathrm{c} \pm 0.31$ & $1.54 \mathrm{~d} \pm 0.08$ & $1.74 \mathrm{a} \pm 0.07$ & $7.64 \mathrm{~d} \pm 0.21$ & $20.8 \mathrm{c} \pm 0.42$ & $114.3 \mathrm{~d} \pm 0.38$ \\
& 2.5 & $5.34 \mathrm{~b} \pm 0.33$ & $1.67 \mathrm{c} \pm 0.11$ & $1.70 \mathrm{a} \pm 0.08$ & $8.68 \mathrm{c} \pm 0.18$ & $26.3 \mathrm{~b} \pm 0.39$ & $126.8 \mathrm{c} \pm 0.64$ \\
\cline { 2 - 8 } & 5.0 & $5.92 \mathrm{~b} \pm 0.4$ & $1.76 \mathrm{~b} \pm 0.12$ & $1.63 \mathrm{ab} \pm 0.12$ & $9.31 \mathrm{~b} \pm 0.23$ & $34.3 \mathrm{a} \pm 0.24$ & $141.7 \mathrm{a} \pm 0.51$ \\
\cline { 2 - 8 } & 10 & $7.14 \mathrm{a} \pm 0.6$ & $1.85 \mathrm{a} \pm 0.18$ & $1.52 \mathrm{~b} \pm 0.14$ & $10.51 \mathrm{a} \pm 0.19$ & $36.7 \mathrm{a} \pm 0.36$ & $149.3 \mathrm{~b} \pm 0.67$ \\
\cline { 2 - 8 } & 0 & $6.34 \mathrm{c} \pm 0.54$ & $1.68 \mathrm{~cd} \pm 0.09$ & $3.89 \mathrm{a} \pm 0.16$ & $11.91 \mathrm{c} \pm 0.30$ & $26.9 \mathrm{~d} \pm 0.35$ & $125.8 \mathrm{~d} \pm 0.71$ \\
\hline \multirow{3}{*}{10} & 2.5 & $6.98 \mathrm{c} \pm 0.61$ & $1.76 \mathrm{c} \pm 0.13$ & $3.01 \mathrm{a} \pm 0.15$ & $11.75 \mathrm{c} \pm 0.27$ & $31.3 \mathrm{c} \pm 0.11$ & $135.3 \mathrm{c} \pm 0.89$ \\
\cline { 2 - 8 } & 5.0 & $8.93 \mathrm{a} \pm 0.6$ & $2.63 \mathrm{a} \pm 0.09$ & $1.95 \mathrm{c} \pm 0.09$ & $13.51 \mathrm{a} \pm 0.33$ & $44.7 \mathrm{a} \pm 0.46$ & $169.2 \mathrm{a} \pm 0.46$ \\
\cline { 2 - 8 } & 10 & $7.85 \mathrm{~b} \pm 0.58$ & $2.26 \mathrm{~b} \pm 0.13$ & $2.32 \mathrm{~b} \pm 0.14$ & $12.43 \mathrm{~b} \pm 0.27$ & $40.6 \mathrm{~b} \pm 0.37$ & $151.6 \mathrm{~b} \pm 0.56$ \\
\hline
\end{tabular}

Gas exchange and leaf relative humidity : Increasing the concentration of diatomite in the soil , elevated each of the photosynthetic rates, the stomatal conductance, \%of leaf relative humidity $(\% \mathrm{LRH})$ and the net intercellular $\mathrm{CO}_{2}$ concentration $(\Delta$ $\mathrm{CO}_{2}$ ) in Vicia faba leaves, whereas it reduced the transpiration rates at both ages of growth (6 and10 weeks )as compared to untreated plants. Similar results were reported by Amador et al (2005), concerning the stimulating effects of Si on each of net photosynthetic rates, stomatal conductance, photochemical efficiency of photo system $\Pi$, intercellular $\mathrm{CO}_{2}$, net $\mathrm{CO}_{2}$ assimilation rates and its reducing effect on the transpiration rates in several examined plants. Such reduction was attributed to the deposition of $\mathrm{Si}$ as colloidal silica gel $\left(\mathrm{SiO}_{2}\right)$ in the xylem vessels and the cell walls of leaves which thus restrict the bypass flow of transpired water that crosses the root cells towards the xylem vessels following an apoplastic pathway( $\mathrm{Ma}$ and Yamaji,
2006; Savvas et al, 2009) and present a barrier to cuticular transpiration (Hull, 2004).Both effects increase the relative water content of plants and specially of leaves thus keeping them erect which ,in turn, improves light penetration into plant community thus improving photosynthesis. The enhanced photosynthetic rates in response to $\mathrm{Si}$ causes the promotion of both $\mathrm{NH}_{4}-\mathrm{N}$ assimilation, the supply of cell wall material e.g. cell wall polysaccharides and lignin polymers and the supply of carbohydrates which, in turn, increases both the stem strength that improves the plants resistance to lodging and the root activity that increases the oxidation power of roots and promotes water and nutrient uptake (Hull, 2004) At the other side, the stimulating effect of $\mathrm{Si}$ on $\mathrm{CO}_{2}$ assimilation rates could be attributed to the sustainable effect of this element on the activities of ribulose-bis phosphate carboxylase and NADP+ dependent glyceralde-3 phosphate dehydrogenase enzymes (Gong et al ,2005).

Table 4. Changes in gas exchange measurements and percentage of leaf relative humidity (\%LRH) of Vicia faba plants in response to diatomite treatment .Each value is a mean of ten replicates ( $\pm S D$ ).

\begin{tabular}{|c|c|c|c|c|c|c|}
\hline Age/week & $\begin{array}{l}\text { Concentra } \\
\text { tion }(\mathbf{g} / \mathbf{k g})\end{array}$ & $\begin{array}{l}\text { Photosynthetic } \\
\text { rate }(\mu \text { mole } \\
\left.\mathrm{CO}_{2} \mathrm{~m}^{-2} \mathrm{~s}^{-1}\right)\end{array}$ & 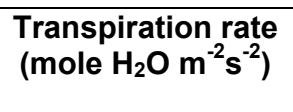 & $\begin{array}{l}\text { Leaf stomatal } \\
\text { conductance } \\
\left(\mathrm{cm} \mathrm{s}^{-1)}\right.\end{array}$ & \%LRH & $\Delta \mathrm{CO}_{2}(\mu \mathrm{mol})$ \\
\hline \multirow{4}{*}{6} & 0 & $7.9 d \pm 0.28$ & $1.92 a \pm 0.11$ & $0.069 d \pm 0.025$ & $26.8 d \pm 0.7$ & $36.6 d \pm 0.78$ \\
\hline & 2.5 & $8.8 c \pm 0.4$ & $1.81 \mathrm{ab} \pm 0.08$ & $0.116 c \pm 0.03$ & $33.4 \mathrm{c} \pm 0.6$ & $47.8 c \pm 0.65$ \\
\hline & 5.0 & $10.7 \mathrm{~b} \pm 0.32$ & $1.63 b \pm 0.07$ & $0.140 \pm 0.02$ & $36.6 b \pm 0.4$ & $56.6 \mathrm{~b} \pm 0.7$ \\
\hline & 10 & $13.9 a \pm 0.5$ & $1.19 c \pm 0.09$ & $0.190 a \pm 0.04$ & $38.4 a \pm 0.3$ & $67.2 a \pm 0.6$ \\
\hline \multirow{4}{*}{10} & 0 & $12.6 \mathrm{~cd} \pm 0.29$ & $3.16 a \pm 0.27$ & $0.198 c \pm 0.013$ & $33.2 d \pm 0.7$ & $48.1 d \pm 0.72$ \\
\hline & 2.5 & $13.7 c \pm 0.30$ & $2.69 b \pm 0.33$ & $0.234 b \pm 0.03$ & $36.1 \mathrm{c} \pm 0.8$ & $63.6 c \pm 0.66$ \\
\hline & 5.0 & $19.8 a \pm 0.43$ & $2.14 b c \pm 0.41$ & $0.367 a \pm 0.015$ & $42.3 a \pm 0.5$ & $89.3 a \pm 0.81$ \\
\hline & 10 & $16.4 b \pm 0.51$ & $2.39 b \pm 0.29$ & $0.284 b \pm 0.01$ & $38.6 \mathrm{~b} \pm 0.6$ & $74.5 b \pm 0.76$ \\
\hline
\end{tabular}


Total nitrogen, total soluble nitrogen and some mineral element contents : Application of diatomites at all rates apparently raised the values of each of total nitrogen (TN), Total soluble nitrogen $(T S N)$, phosphorus $(\mathrm{P})$, potassium $(\mathrm{K})$, calcium $(\mathrm{Ca})$ and magnesium $(\mathrm{Mg})$, whereas it decreased the amounts of both sodium ( $\mathrm{Na}$ ) and iron $(\mathrm{Fe})$ above and below the untreated control plants respectively so as to reach peak levels at rates 10 and $5 \mathrm{~g} / \mathrm{kg}$ soil at ages 6 and 10 weeks successively (see table 5). The effect of $\mathrm{Si}$ on the $\mathrm{N}$ and tissue element contents have been previously reported by several authors using several plants. For instance, Islam and Saha (1969) found that Si application(200ppm) generally decreased the uptake of $\mathrm{N}, \mathrm{K}, \mathrm{Fe}$ and $\mathrm{Mn}$ in trans planted rice and increased the uptake of $\mathrm{P}, \mathrm{Ca}, \mathrm{Mg}$ and the formation of carbohydrates. In another experiment using golden pothos plants, $\mathrm{Si}$ application resulted in the suppression of $\mathrm{Al}, \mathrm{Mn}, \mathrm{Na}$ and the mediation of the uptake of other as $\mathrm{P}, \mathrm{Mg}, \mathrm{K}$, $\mathrm{Fe}, \mathrm{Cu}$, and $\mathrm{Zn}$ which causes the balance of nutrient elements in plant tissues (Chen et al, 2001). Many reports viewed that soil treatment with biogeochemically active Si substances, like diatomite, optimizes fertility through improved water, physical and chemical soil properties and maintenance of nutrients in plant -available from (Ma et al ,2001) . The optimization of Si plant nutrition increases the plant resistance to both biotic and abiotic stresses as water and salt stresses. This could be achieved via several routes (i) improving photosynthetic activity that improves the supply of carbohydrates which thus increases root activity, root oxidation power and promotes water and nutrient uptake, (ii) enhanced the ratio of $\mathrm{K}: \mathrm{Na}$ selectivity, uptake and translocation from roots to shoots which was attributed to $\mathrm{Si}$ induced stimulation of the root plasma membrane $\mathrm{H}^{+}$ATPase under salt stress and/or to the reduction in transpiration rates which arose from $\mathrm{Si}$ deposition in cell wall of leaves causing the partial blockage of the transpirational by pass flow thus reducing salinity (Liang et al ,2007; Savvas et al, 2009 ). Fe,Mn and Al are often found to be less toxic in the presence of $\mathrm{Si}$. Si form complexes with these metals and binds them in the root cell walls, thus suppressing their transport to shoots in $\mathrm{Si}$ - accumulator an non- accumulator plants (Hull,2004). Appropiate Si application (15mmol/l ) enhanced both absorbability, utilization ability and the content of $P$ in different organs of maize seedlings under low $\mathrm{P}$ - level. There was also a remarkable positive correlation between $\mathrm{Si}$ and $\mathrm{P}$ accumulation and the correlation coefficient was 0.9683 which induced a synergisitic effect on plant growth (Yang et al, 2008). In another trial, using zucchini and zinnia plants, Si application at an optimum concentration $(50 \mathrm{mg} / \mathrm{l})$ induce the maximum accumulation of $\mathrm{Ca}, \mathrm{P}$ and $\mathrm{Mn}$ and therefore enhanced growth of both plants (Tesfagiorgis et al, 2008). It is well known that $P$ is a constituent of nucleic acids, phosholipids, most essential coenzymes (e.g. NAD, ATP, FAD ), nucleoproteins, cell membranes...etc, thus, it is a pre-requisite for all essential plant processes; whereas $\mathrm{Ca}$ is a constituent of the middle lamella and cell wall and is involved in mitotic spindle organization, thus it is necessary for normal mitosis and normal growth (Devlin and Witham, 1983).

Other studies have shown that Si nutrition in sugar cane and symbiotic legumes increased $\mathrm{NH}_{3}$ assimilation in both and increased nodulation, $\mathrm{N}_{2}$ fixation and $\mathrm{N}_{2}$ reduction thus increasing the wholeplant mechanical strength (Dakora, 2005). It was suggested that $\mathrm{Si}$ increases the photosynthetic activity which increases the supply of carbon skeleton that increased the demand of $\mathrm{N}$ for the synthesis of amino acids and other $\mathrm{N}$ compounds (Lima Filho and Abdalla, 2008).

\section{Biochemical genetic markers(SDS-protein} electrophoresis): SDS- electrophoretic patterns of leaf total protein of the diatomite- treated and untreated plants at both ages of growth (6and 10weeks ) are shown in table (6) and figure (1). The maximum number of bands were 28 having molecular weights ranged from 355 to $11 \mathrm{kD}$. Among such bands, 12 bands were commonly detected while the other 16 bands showed high variability due to different diatomite treatment $(2.5,5$ and $10 \mathrm{~g} / \mathrm{kg}$ soil $)$. The plants treated with $10 \mathrm{~g} / \mathrm{kg}$ diatomites revealed the highest number of variable protein bands (22and23bands after 6and 10 weeks respectively), while each of the control and plants treated with $5 \mathrm{~g} / \mathrm{kg}$ (after 6weeks) or $2.5 \mathrm{~g} / \mathrm{kg}$ (after 10 weeks ) showed the least numbers (20 bounds). With the increase in age of plants, the number of total protein bands were similarly raised in all diatomite -treated plants except those treated with the lowest rate $(2.5 \mathrm{~g} / \mathrm{kg})$ which reversibly decreased with age. Three unique bands with 300, 90 and 25KDwere deteced in all treated and untreated plants after 6weeks but disappeared at the next age. Moreover, some bands appeared in the control an in the two lower treatments after 6 weeks and subsequently appeared in the plants treated with both 5 and $10 \mathrm{~g} / \mathrm{kg}$ diatomite after 10 weeks ( 355 and $11 \mathrm{KD}$ ). The obtained results 
demonstrated the effectiveness of diatomite treatments to recover and conserve the genetic background of the plants by restoring and maintaining the protein bands especially at the highest diatomite rate $(10 \mathrm{~g} / \mathrm{kg})$.

Reversibly, there were another induced bands which were absent after 6 weeks and appeared in all diatomite- treated plants at the latter age. For instance, after 10 weeks ; two bands with 53 and $32 \mathrm{KD}$ appeared at all treatments; a band with 104KD appeared at 5 and $10 \mathrm{~g} / \mathrm{kg}$ and a fourth band with 100KD appeared at all concentrations in addition to the highest concentrations after 6 weeks. Diatomite application at the lowest rate $(2.5 \mathrm{~g} / \mathrm{kg})$ induced two distinctive bands at 26 and 23KD after 10 and 6 weeks respectively, while another band (210KD) appeared a the highest rate after 6 weeks. On the other hand, diatomite treatment at all rates and a both ages, induced three distinguish bands which didn't exist in the control (289, 45 and 34KD). The obtained induced and restored protein bands confirmed the significance of diatomite as a distinctive algal manure in accelerating the gene function to perform and encourage, in an elevated rate, new silence genes to operate, which was demonstrated by the new gene expression (protein profiles ) obtained using SDS-PAGE analysis in Table (6).

Consistent with this work, several workers reported that $\mathrm{Si}$ application increase the content of total soluble proteins and decreased the amount of protein carbonyl (oxidative proteins) in wheat (Gong et al ,2005 and 2008 ). Furthermore, $\mathrm{Si}$ acts on mechanisms shared by all plant species that leads to the expression of plant stress genes (signaling cascades) as a natural defense response that translate and activate a strategic signalling protein known as proline-rich protein (PRprotein ) and mitogen activated protein kinases (MAP- kinases). These proteins transmit information to the nucleus by the phosphorylation of hydroxyl group on amino acid residues. Si is known to bind to hydroxyl groups and may thus affect protein activity or conformation, Accordingly, Si acts as a modulator and a potentiator of plant defense responses against abiotic and biotic stresses (Fauteux et al , 2005).

Table 5. Changes in total nitrogen, total soluble- $\mathrm{N}$ and certain mineral contents in response to diatomite treatment . Each value is a mean of 5 replicates and expressed as $\mathrm{mg} / \mathrm{g} . \mathrm{d} . \mathrm{wt}$. ( \pm SD).

\begin{tabular}{|c|c|c|c|c|c|c|c|c|c|}
\hline $\begin{array}{l}\text { Age/w } \\
\text { eek }\end{array}$ & $\begin{array}{l}\text { Concen } \\
\text { tration } \\
\text { (g/kg) }\end{array}$ & $\begin{array}{l}\text { Total } \\
\text { Nitrogen }\end{array}$ & $\begin{array}{l}\text { Total } \\
\text { soluble- } \\
\text { nitrogen }\end{array}$ & $\begin{array}{l}\text { Phosphor } \\
\text { us }\end{array}$ & Potassium & Sodium & $\begin{array}{l}\text { Calciu } \\
\text { m }\end{array}$ & $\begin{array}{l}\text { Magnesi } \\
\text { um }\end{array}$ & Iron \\
\hline \multirow[t]{4}{*}{6} & 0 & $\begin{array}{l}66.9 \mathrm{c} \pm \\
0.73\end{array}$ & $\begin{array}{l}72 . d \pm \\
0.89\end{array}$ & $\begin{array}{l}16.35 \mathrm{~cd} \pm 0 \\
.76\end{array}$ & $4.2 \mathrm{~cd} \pm 0.1$ & $3.2 \mathrm{a} \pm 0.01$ & $\begin{array}{l}12.6 \mathrm{~d} \\
\pm 0.3\end{array}$ & $\begin{array}{l}8.42 d \pm \\
0.65\end{array}$ & $\begin{array}{l}1.51 a \pm \\
0.02\end{array}$ \\
\hline & 2.5 & $\begin{array}{l}72.4 \mathrm{~b} \pm \\
0.60\end{array}$ & $\begin{array}{l}13.4 \mathrm{C} \pm \\
0.54\end{array}$ & $\begin{array}{l}17.91 \mathrm{c} \pm \\
0.84\end{array}$ & $5.6 c \pm 0.09$ & $3.0 a \pm 0.06$ & $\begin{array}{l}13.9 \mathrm{c} \\
\pm 0.6\end{array}$ & $\begin{array}{l}10.41 \mathrm{c} \pm \\
0.32\end{array}$ & $\begin{array}{l}1.48 \pm \\
0.03\end{array}$ \\
\hline & 5.0 & $\begin{array}{l}78.5 b \pm \\
0.38\end{array}$ & $\begin{array}{l}14.8 b \pm \\
0.63 \\
\end{array}$ & $\begin{array}{l}19.43 b \pm \\
0.91\end{array}$ & $6.9 b \pm 0.05$ & $2.6 b \pm 0.04$ & $\begin{array}{l}14.3 \mathrm{~b} \\
\pm 0.5 \\
\end{array}$ & $\begin{array}{l}11.59 \mathrm{~b} \pm \\
0.21\end{array}$ & $\begin{array}{l}1.42 \mathrm{ab} \pm \\
0.06 \\
\end{array}$ \\
\hline & 10 & $\begin{array}{l}81.2 \mathrm{a} \pm \\
0.41\end{array}$ & $\begin{array}{l}17.6 \mathrm{a} \pm \\
0.82\end{array}$ & $\begin{array}{l}22.66 a \pm \\
0.90\end{array}$ & $7.8 a \pm 0.08$ & $2.0 \mathrm{~b} \pm 0.09$ & $\begin{array}{l}15.8 \mathrm{a} \\
\pm 0.7\end{array}$ & $\begin{array}{l}13.36 a \pm \\
0.44\end{array}$ & $\begin{array}{l}1.36 \mathrm{~b} \pm \\
0.04\end{array}$ \\
\hline \multirow[t]{4}{*}{10} & 0 & $\begin{array}{l}54.6 \mathrm{~b} \pm \\
0.54\end{array}$ & $\begin{array}{l}11.8 \mathrm{c} \pm \\
0.82\end{array}$ & $\begin{array}{l}26.38 d \pm \\
0.73\end{array}$ & $5.4 c \pm 0.03$ & $4.8 a \pm 0.06$ & $\begin{array}{l}16.4 d \pm \\
0.81\end{array}$ & $\begin{array}{l}12.96 \pm \\
0.39\end{array}$ & $\begin{array}{l}0.98 a \pm \\
0.04\end{array}$ \\
\hline & 2.5 & $\begin{array}{l}58.3 b \pm \\
0.34\end{array}$ & $\begin{array}{l}15.9 \mathrm{~b} \pm \\
0.91\end{array}$ & $\begin{array}{l}29.45 c \pm \\
0.92\end{array}$ & $9.8 a \pm 0.07$ & $\begin{array}{l}3.7 a b \pm \\
0.09\end{array}$ & $\begin{array}{l}19.2 \mathrm{c} \pm \\
0.63\end{array}$ & $\begin{array}{l}14.68 \pm \\
0.74 \\
\end{array}$ & $\begin{array}{l}0.62 \mathrm{~b} \pm \\
0.05\end{array}$ \\
\hline & 5.0 & $\begin{array}{l}69.7 a \pm \\
0.82\end{array}$ & $\begin{array}{l}20.1 \mathrm{a} \pm \\
0.61\end{array}$ & $\begin{array}{l}35.64 a \pm \\
0.66\end{array}$ & $8.3 b \pm 0.21$ & $\begin{array}{l}3.0 \mathrm{bc} \pm \\
0.08\end{array}$ & $\begin{array}{l}26.9 a \pm \\
0.72\end{array}$ & $\begin{array}{l}19.91 \pm \\
0.68\end{array}$ & $\begin{array}{l}0.47 \mathrm{c} \pm \\
0.08\end{array}$ \\
\hline & 10 & $\begin{array}{l}63.9 a \pm \\
0.9\end{array}$ & $\begin{array}{l}19.8 \mathrm{ab} \pm \\
0.7\end{array}$ & $\begin{array}{l}32.04 \pm \\
0.46\end{array}$ & $8.2 b \pm 0.46$ & $3.6 b \pm 0.09$ & $\begin{array}{l}22.1 \mathrm{~b} \pm \\
0.68\end{array}$ & $\begin{array}{l}17.63 \pm \\
0.81\end{array}$ & $\begin{array}{l}0.39 d \pm \\
0.09\end{array}$ \\
\hline
\end{tabular}


Table (6). SDS-PAGE analysis of protein bands of faba bean after six and ten weeks of diatomite treatments.

\begin{tabular}{|c|c|c|c|c|c|c|c|c|c|}
\hline \multirow{3}{*}{$\begin{array}{c}\text { Band } \\
\text { No. }\end{array}$} & \multirow{3}{*}{$\begin{array}{l}\text { MW } \\
\text { (kD) }\end{array}$} & \multicolumn{8}{|c|}{ Band $\%$} \\
\hline & & \multicolumn{4}{|c|}{6 weeks } & \multicolumn{4}{|c|}{10 weeks } \\
\hline & & Cont. & 2.5 & 5 & 10 & Cont. & 2.5 & 5 & 10 \\
\hline 1 & 355 & 2.9 & 2.9 & 1.9 & & 1.8 & & 1.9 & 2.8 \\
\hline 2 & 300 & 3.6 & 1.6 & 3.1 & 4.2 & 6.8 & & & \\
\hline 3 & 289 & & 2.0 & 2.4 & 2.4 & & 2.9 & 2.3 & 4.1 \\
\hline 4 & 234 & 2.9 & 1.8 & 1.4 & 2.8 & 5.3 & 3.1 & 3.5 & 2.4 \\
\hline 5 & 210 & 3.3 & & & 2.7 & 4.0 & & & \\
\hline 6 & 115 & 3.9 & 2.2 & 2.0 & 2.9 & 5.2 & 2.8 & 4.8 & 2.7 \\
\hline 7 & 112 & 2.6 & 1.9 & & 3.7 & 8.0 & 4.3 & 2.7 & 4.5 \\
\hline 8 & 110 & 2.3 & 1.6 & 7.1 & 1.8 & 6.7 & 3.9 & 1.5 & 4.6 \\
\hline 9 & 104 & & & & & & & 6.3 & 4.3 \\
\hline 10 & 100 & & & & 4.5 & & 3.8 & 3.8 & 4.1 \\
\hline 11 & 95 & 12.2 & 13.0 & 5.7 & 6.8 & 9.0 & 10.0 & 14.3 & 9.4 \\
\hline 12 & 90 & 5.0 & 8.8 & 6.3 & 6.7 & 3.9 & & & \\
\hline 13 & 83 & 5.5 & 2.0 & 3.8 & 2.7 & 4.8 & 4.8 & 5.7 & 1.5 \\
\hline 14 & 76 & 4.2 & 2.8 & 4.3 & 2.8 & 7.6 & 10.8 & 3.8 & 2.5 \\
\hline 15 & 61 & 9.5 & 9.3 & 4.6 & 7.2 & 5.0 & 5.0 & 6.7 & 9.7 \\
\hline 16 & 53 & & & & & & 11.1 & 3.0 & 4.9 \\
\hline 17 & 45 & & 3.5 & 9.6 & 4.3 & & & & \\
\hline 18 & 43 & 5.0 & 4.3 & 9.3 & 4.9 & 5.0 & 3.7 & 8.4 & 11.0 \\
\hline 19 & 41 & 4.0 & 10.6 & 6.4 & 3.0 & 4.0 & 8.7 & 8.7 & 7.1 \\
\hline 20 & 39 & 6.8 & 5.8 & 13.7 & 3.5 & 6.8 & 10.1 & 5.7 & 5.1 \\
\hline 21 & 37 & 5.6 & 6.1 & 5.0 & 6.0 & 5.6 & 6.0 & 4.2 & 2.3 \\
\hline 22 & 34 & & 4.4 & 5.7 & 10.5 & & & & \\
\hline 23 & 32 & & & & & & 8.7 & 1.7 & 1.2 \\
\hline 24 & 26 & & & & & & 6.6 & & \\
\hline 25 & 25 & 3.6 & 3.2 & 1.5 & 8.0 & 3.6 & & & 2.2 \\
\hline 26 & 23 & 2.1 & 6.2 & & & 2.1 & & & \\
\hline 27 & 15 & 4.7 & 6.0 & 9.0 & 4.9 & 4.7 & 2.8 & 4.1 & 2.1 \\
\hline 28 & 11 & 2.0 & & 2.5 & 3.8 & 2.0 & & 2.1 & 2.0 \\
\hline & Total bands & 20 & 21 & 20 & 22 & 20 & 20 & 22 & 23 \\
\hline & No.of new bands & 0 & 3 & 3 & 4 & 0 & 7 & 7 & 7 \\
\hline No. & appeared bands & 8 & 2 & 3 & 2 & 7 & 7 & 5 & 4 \\
\hline
\end{tabular}

Isozyme polymorphism: Four enzymes; esterase ( EST), peroxidase (POD), catalase (CAT) and acid phosphatase $(A C P)$ were used to detect the variation of Vicia faba isozymes after fertilization with different concentration of diatomites $(2.5,5$ and $10 \mathrm{~g} / \mathrm{kg}$ soil) at ages 6 and 10 week. The electrophoretic pattern of the enzymes was presented in figure (2). EST isozymes analysis (table 7 ), displayed 13 bands, six of them were polymorphic with different genetic responses while the other bands were similar. Four EST isozyme bands were induced due to diatomite treatment $(6,7,10$ and 11$)$ and was not existing in the control ,the first and second bands appeared at the highest rate $(10 \mathrm{~g} / \mathrm{kg})$ and at both the lower and medium rates $(2.5$ and $5 \mathrm{~g} / \mathrm{kg}$ ) respectively after 6 weeks, whereas the third and fourth bands appeared at both ages due to treatment with both the medium and highest rates (after 6 weeks and at all diatomite rates after 10 weeks ) respectively. Conversely, two other polymorphic bands (8 and 2 ) appeared in the control and in either all or the lower and medium concs. (2.5 and $5 \mathrm{~g} / \mathrm{kg}$ ) respectively after 6 weeks, but at the next age (10 weeks ) they mostly disappeared under all concentrations.

POD isozymes exhibited 3 polymorphic bands among the total of seven. It is interesting to note that 2 of the 3 bands were absent after 6 weeks either under all diatomite concentration (band no. 6 ) or under the higher concentrations 5 and $10 \mathrm{~g} / \mathrm{kg}$ (bands no. 3) but appeared at the 3 diatomite rates at the next age (table 7). 
Agric. Biol. J. N. Am., 2010, 1(5): 1076-1089

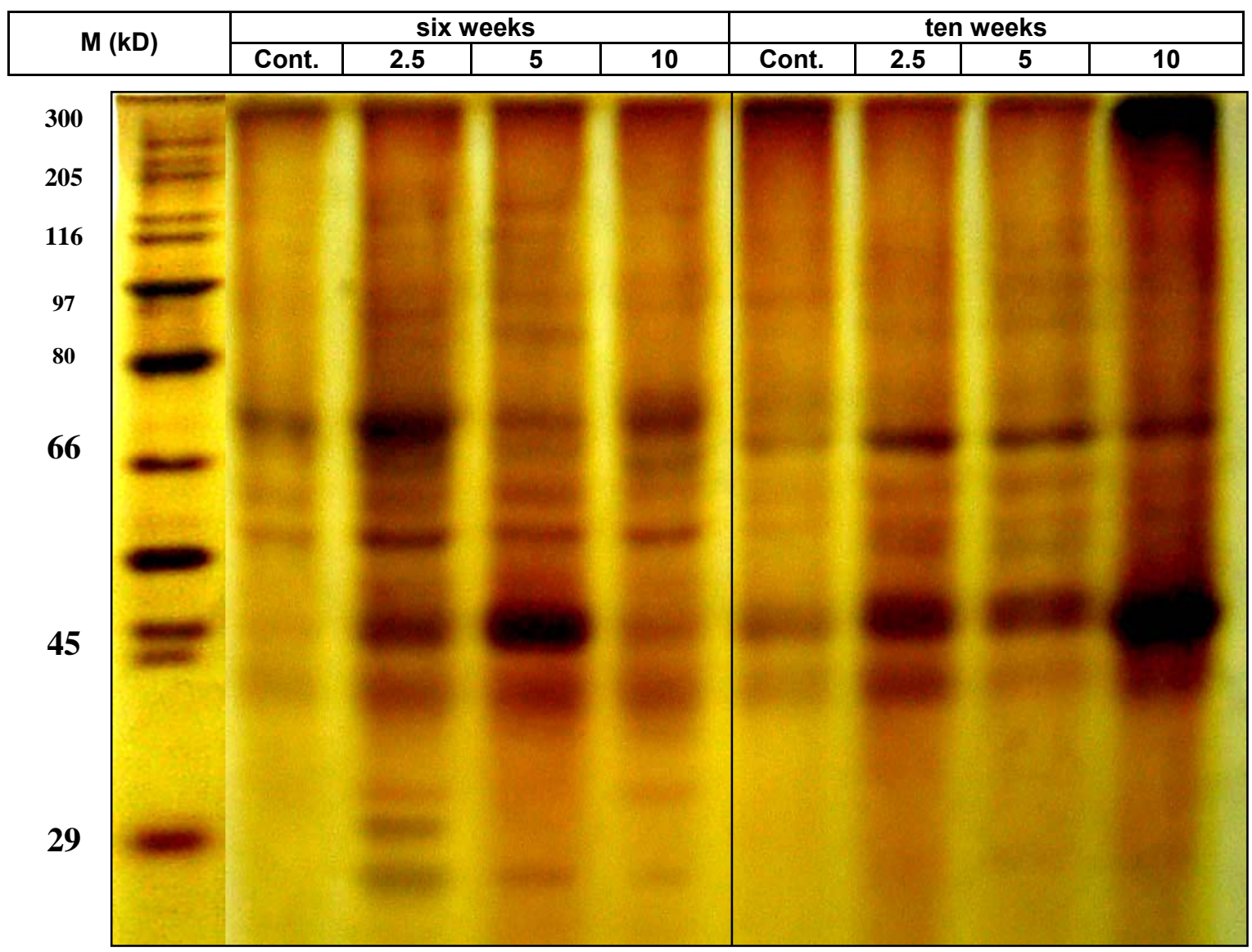

Fig 1. SDS-PAGE profile of protein bands of faba bean after six and ten weeks of diatomite treatments.M, referred to the protein standard marker with kilo Daltons (kDs) molecular weights. 
Agric. Biol. J. N. Am., 2010, 1(5): 1076-1089

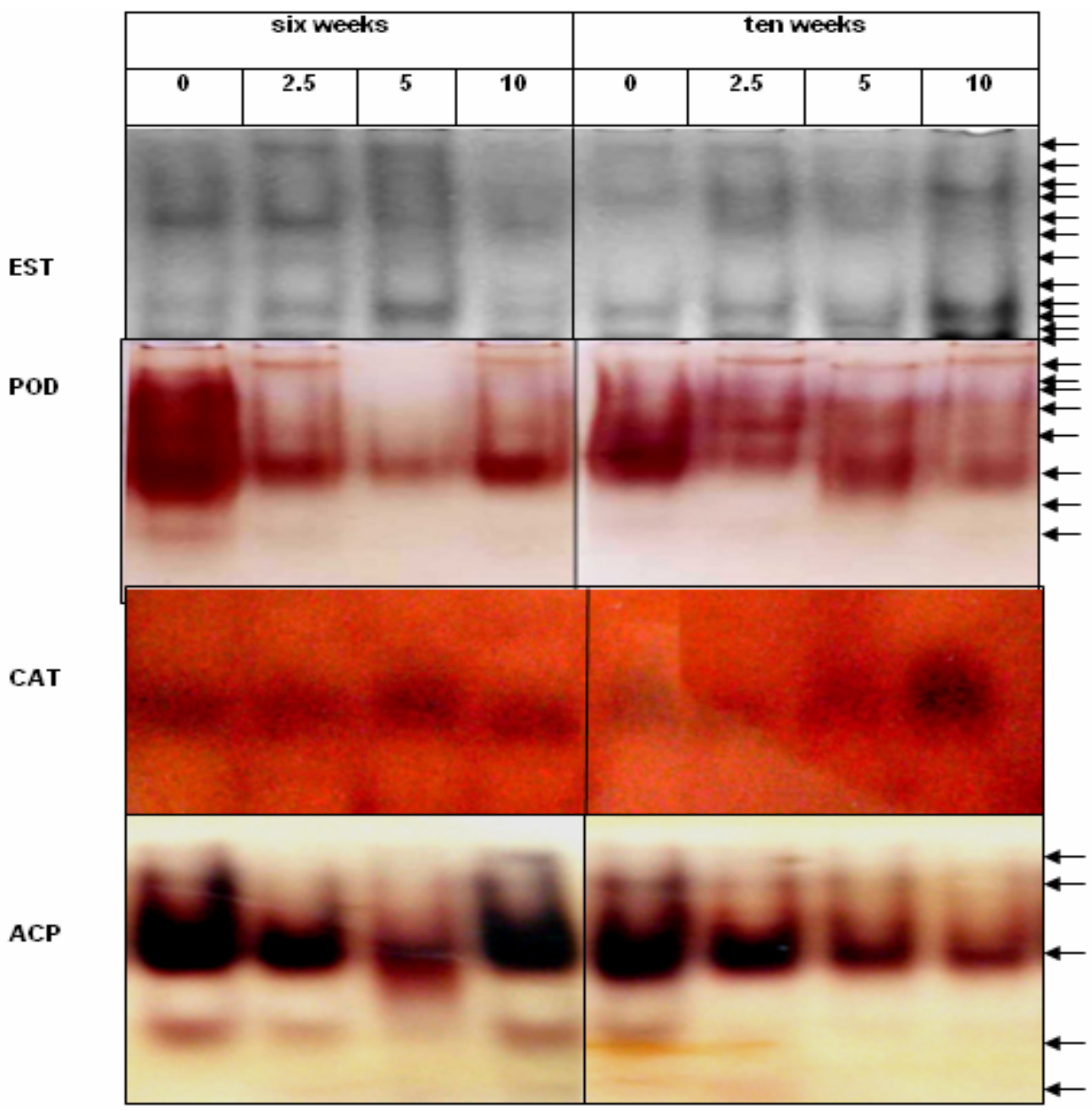

Fig 24

Isozyme electrophoretic zymograms of four enzymes of faba bean after six and ten weeks of diatomite treatments. 
Table 7. Variable bands of four enzymes of faba bean after six and ten week treatments.

\begin{tabular}{|c|c|c|c|c|c|c|c|c|c|}
\hline \multirow{2}{*}{ Enzymes } & \multirow{2}{*}{$\begin{array}{c}\text { Band } \\
\text { No. }\end{array}$} & \multicolumn{4}{|c|}{ SIX weeks } & \multicolumn{4}{|c|}{ ten weeks } \\
\hline & & Cont. & 2.5 & 5 & 10 & Cont. & 2.5 & 5 & 10 \\
\hline \multirow{13}{*}{ EST } & 1 & 170 & 183 & 193 & 128 & 170 & 128 & 127 & 138 \\
\hline & 2 & 183 & 176 & 197 & & 183 & 182 & & \\
\hline & 3 & 194 & 192 & 199 & 166 & 194 & 186 & 167 & 204 \\
\hline & 4 & 193 & 197 & 187 & 170 & 193 & 152 & 168 & 196 \\
\hline & 5 & 212 & 209 & 204 & 166 & 212 & 135 & 150 & 185 \\
\hline & 6 & & & & 131 & & & & \\
\hline & 7 & & 131 & 181 & & & & & \\
\hline & 8 & 105 & 118 & 138 & 103 & 105 & & & \\
\hline & 9 & 128 & 135 & 130 & 73 & 128 & 131 & 131 & 218 \\
\hline & 10 & & & 181 & & & & 134 & \\
\hline & 11 & & & & 61 & & 77 & 163 & 197 \\
\hline & 12 & 141 & 151 & 109 & 105 & 141 & 141 & 121 & 215 \\
\hline & 13 & 187 & 225 & 204 & 233 & 187 & 212 & 131 & 227 \\
\hline \multirow{7}{*}{ PRX } & 1 & 110 & 117 & 78 & 116 & 110 & 136 & 96 & 127 \\
\hline & 2 & 193 & & & & 193 & 129 & & \\
\hline & 3 & 218 & 115 & & & 218 & 183 & 164 & 160 \\
\hline & 4 & 219 & 170 & 126 & 171 & 219 & 202 & 183 & 163 \\
\hline & 5 & 223 & 189 & 173 & 200 & 223 & 203 & 200 & 178 \\
\hline & 6 & 191 & & & & 191 & 84 & 133 & 94 \\
\hline & 7 & 138 & 124 & 170 & 88 & 138 & 83 & 79 & 70 \\
\hline \multirow{3}{*}{ CAT } & 1 & & & 36 & & & & & 31 \\
\hline & 2 & 21 & 31 & 36 & 91 & 21 & 59 & 35 & 35 \\
\hline & 3 & & & & 43 & & & & 55 \\
\hline \multirow{5}{*}{ ACP } & 1 & 21 & 22 & 20 & 20 & 21 & 28 & 34 & 33 \\
\hline & 2 & 11 & 20 & 23 & 17 & 11 & 26 & 67 & 67 \\
\hline & 3 & 8 & 27 & 25 & 16 & 8 & 27 & & \\
\hline & 4 & 60 & 32 & 31 & 27 & 60 & & & \\
\hline & 5 & & & & 21 & & 24 & & \\
\hline
\end{tabular}

CAT isozyme showed two induced polymorphic bands (1and 3 ) among the total of three due to diatomite fertilization which did not exist in the control. They were inducted either under $5 \mathrm{~g} / \mathrm{kg}$ (bands no. 1) or at $10 \mathrm{~g} / \mathrm{kg}$ (bands no 3) after 6 weeks while they appeared only under $10 \mathrm{~g} / \mathrm{kg}$ after 10 weeks.

ACP isozyme showed three polymorphic bands of the total five. It was less affected by diatomite treatment in comparison to the other isozyme. After 6 weeks, band no 3 and 4 appeared in the control and the 3 different diatomite concentrations, while band no 5 was only induced under $10 \mathrm{~g} / \mathrm{kg}$. After 10 weeks, band no. 3 and 5 continued to appear at only the lowest rate $(2.5 \mathrm{~g} / \mathrm{kg})$. In regard to band intensity and density, the medium concentration $(5 \mathrm{~g} / \mathrm{kg})$ showed the most intensive esterase isozyme bands as compared to either treated or untreated plants after 6 weeks. Thus, they recorded 197,181, 138, 181 for bands no.2,7,8 and 10 respectively. After 10 weeks, the highest concentration of diatomite $(10 \mathrm{~g} / \mathrm{kg})$ displayed the highest intensive band (197) for band no.11. The band no 3 of CAT isozyme was 43 and increased to 55 after 6 and 10 weeks respectively under the highest rate $(10 \mathrm{~g} / \mathrm{kg})$.

The obtained results are in agreement with many available reports. For instance, Gong et al (2005 and 2008) investigated that $\mathrm{Si}$ application decreased the content of hydrogen peroxide $\left(\mathrm{H}_{2} \mathrm{O}_{2}\right)$, the activities of peroxidase, acid phospholipases and lipoxygenase enzymes whereas it increased the activities of catalase and superoxide dismutase (SOD) in wheat cultivars under drought. Si also increased leaf and root SOD, POD, CAT and glutathione reductase (GR) activities and the glutathione (GSH) concentration but suppressed the malondialdehyde (MDA) content in barley under salt stress. Si, moreover, stimulated root $\mathrm{H}^{+}$ATPase and $\mathrm{H}^{+}$PPase activity in the plasma 
membranes and tonoplasts and decreases their permeability, thus increasing the integrity, stability and functioning of membrane (Liang et al, 2006; Savvas et al, 2009). The effect of Si was found to be time-dependent and became stronger as the experiment continued. The higher activity of antioxidant enzymes and isozymes electrophoretic banding patterns are dependent on the silicon treatment . This biochemical component may be used as a marker to protect the plant tissues from oxidative damage induced by abiotic and biotic stresses ( Gong et al,2005; Tale Ahmad and Haddad ,2008). Other work showed that the activities of antioxidant enzymes and lipid peroxidation (MDA)decreased with the increase in Si rates which suggest a protective effect of Si against overproduction of reactive oxygen species (ROS) as superoxide, hydrogen peroxide and hydroxyl radicals that may be produced due to either metabolic processes or due to environmental and disease stresses ( Gong et al , 2005 and Lima Filho et al ,2005). Concerning the impact of silicon on estarse enzyme activities and its isozymes electrophoretic pattern, there is dearth of the available data.

In the present work, the results manifested that the uptake of silicon as diatomites by faba bean (Vicia faba ) plants benefits its growth and development , although $\mathrm{Si}$ hasn't been classified as an essential element that forms a part of plant constituents or metabolites like other identified elements, in general, and for faba bean plants, in particular, since faba beans has been classified in previous works as $\mathrm{Si}-$ excluder plants. Based on current knowledge, It can be concluded that $\mathrm{Si}$ is not inert, but acts as a physical or mechanical barrier in plants. It is not only deposited in the call walls, but is also actively involved in the metabolic and /or physiological activities, especially in plants subject to multiple stresses. In fact, diatomite treatment raised all growth criteria , chlorophyll $a$ and $b$, total pigment, total soluble sugars, total sugars, total soluble nitrogen and total nitrogen concentrations. It also increased the values of phosphorus, potassium, calcium and magnesium and induced new electrophoretic protein bands and new polymorphic isozyme (EST,POD,CAT and ACP) electrophoretic bands while caused the disappearance of another bands. Moreover, diatomites increased the photosynthetic rates, the leaf stomatal conductance, the net intercellular $\mathrm{CO}_{2}$ and the \%of leaf relative humidity (LRH). Reversibly, diatomites caused the decrease in each of transpiration rate and the concentrations of each of carotenoids, sodium and iron.

Collectively, Si fertilization has a multiple effect on the soil-plant system. Firstly, improved plant Si nutrition reinforces plant protective properties against diseases, insect attack and unfavourable climatic conditions by enhancing the morphological features concomitant with the physiological and metabolic activities of plants. Secondly, Si optimizes soil fertility through improving soil water, physical and chemical properties and maintaining nutrients in plant available forms (Matichenkov and Kosobrukhov, 2004).

It is thus evident from this work and from the literature that, $\mathrm{Si}$ in the from of diatomites or other similar natural products should be used more extensively than they are presently. Frankly, silicon fertilizers are not used more extensively world- wide because there is a critical lack of specialists working to show the importance of $\mathrm{Si}$ as a fertilizer material . Moreover, knowledge of benefits of $\mathrm{Si}$ fertilization must be translated into practical and economic strategies based on suitable safe products to underpin impotents in crop yield and quality while arresting degradation of the soil environment. Further studies should be also focused on Si uptake and translocation in various plant species. This process varies greatly among plants depending on whether they are accumulating or non- accumulating and on the controlling genes. Such uptake genes needs to be cloned, isolated and characterized in different plants in the near future like those of rice plants .Furthermore, given that most plants, particularly dicots, cannot accumulate $\mathrm{Si}$ in large enough amounts to be beneficial, genetically manipulating the Si uptake capacity of the roots might help plants to accumulate more $\mathrm{Si}$ and, hence, more able to overcome both biotic and abiotic stresses.

\section{ACKNOWLEDGEMENTS:}

I express my deepest thanks and gratitude to Dr. Raifa A. Hassanein, Professor of Plant Physiology, Botany Department, Faculty of Science, Ain Shams University and to my dear husband and daughters for their valuable advice, supervision, continuous help and encouragment throughout this work.

\section{REFERENCES}

Amador, B.M.; Yamada ,S.;Yamaguchi, T. ; Hernandez J.L.G.; Aguilar, R.L. ; Dieguez , E.T.;Kaya ,C. and Serrano , N.Y.A. (2005). Effects of silicon on growth, physiological development, mineral nutrition and their 
relation to $\mathrm{NaCl}$ tolerance in two legume species. Silicon in Agriculture Conferencendia / MG.Brazil.

A.O.A.C (1984). Official Method of Analysis of the Association of Official Analytical Chemists, $14^{\text {th }}$ ed, Published by the Association of OfficialAnalytical Chemists , P.O. Box 540 , Benjamin Franklin Station , Washington, dc. 20044.

Barceló, J.; Guevara, P. and Poschenrieder, Ch. (1993) .Silicon amelioration of aluminum toxicity in teosinte (Zea mays L.ssp Mexicana ). Plant Soil 154,249-255.

Chapman ,H.D. and Pratt , F.P. (1961). Method of analysis for soils, plants and waters .Uuniv. of California. Division of Agric . Science

Chen, J.; Caldwell,R.D.; Robinson, C.A. and Steinkamp,R.(2000). Lets put the Si back into the soil. Part I. Plant Nutrition 4,44-46.

Chen,J.; Caldwell ,R.D. ; Robinson C.A. and Steinkamp ,R. (2001). Lets put the back into soil -part II. Plant Nutrition 6,48-51.

Dakora, F.D (2005). Silicon nutrition and $\mathrm{N}_{2}$ fixation in symbiotic legumes III. Silicon in Agriculture Conference,22-26 October, Uberlandia IMGBrazil,135.

Devlin, R.M. and Witham, F.H.(1983). Plant Physiology .fourth edition. Willard Grant Press ,Boston ,USA.

Dubois, M.; Cilles, K.A.; Hamilton, J.K.; Rober, P. A. and Smith, F. (1965). Colorimetric method for determination of sugars related substances, Anal. Chem. 28, 350-365.

Epstein E, (1999)."Silicon" Annual Review Plant Physiol. Plant mol. Biol. 50,641-664.

Fauteux, F.; Remus- Borel, W.; Menzies, J.G. and Belanger, R.R. (2005). Silicon and plant disease resistance against pathogenic fungi. FEMS Microbiol, lett, 249,1-6.

Galvez L., Clark, R.B.; Gourley ,L. M. and Maranville, J.W. (1987). Silicon interaction with manganese and aluminium toxicity in sorghum J. Plant Nutr. 10,11391147.

Goldberg, H.A. and Warner K.G (1997). The staining of acidic proteins on polyacrylamide gels : Enhanced sensitivity and stability of "stain all " staining in combination with silver nitrate .Analyt . Biochem, 251,227-233.

Gong, H.J.; Chen, K.M. ;Zhao, Z.G.; Chen ,G.C. and Zhou ,W.C. (2008). Effects of silicon on defense of wheat against oxidative stress under drought at different developmental stages. Biologia Plantarum 52,3,596.

Gong, H.J.; Zhu, X.Y.; Chen, K.M.; Wang, S.M. and Zhang, C.L. (2005). Silicon alleviates oxidative damage of wheat plants in pots under drought. Plant Sic. 169,313-321.

Horwilz ,W. (2002). Official methods of A.O.A.C. International Gaithersburg, Maryland, 2077-2417,USA.

Hull ,R.J. (2004). Scientists start to recogenize silicon's beneficial effects, Turf grass Trends 3,154.158

Humphries, E.C. (1956). Mineral component and ash analysis. In modern methods of plant Analysis(Peach, K. and Tracey ,M.V.Ed.) 1,148, Springer-Verlag. Berlin.

Islam ,A. and Saha, R. (1969).Effects of silicon on the chemical composition of rice plants. Plant Soil 30,446458.

Kruger, G. (2006). Certification decision for Diatomite de Mozambique code 1959ZA 0600R1 e doc. South Africa. Ecocert Interational . 1,3.

Laemmli , U.K. (1970) . Cleavage of structural proteins during the assembly of the head of bacteriophage $T_{4}$. Nature ,227,680- 685 .

Liang ,Y.; Zhang ,W.; Chan, Q.; Liu,Y. and Ding, R. (2006). Effect of exogenous silicon ( $\mathrm{Si}$ ) on $\mathrm{H}^{+}$ATPase activity, phosphlipids and fluidity of plasma membrane in leaves of salt- stessed barley (Hordeum vulgare L.) .Environ. Exp. Bot. 57,212-219.

Liang , Y.; Sun, W.; Zhu ,Y. and Christie ,P. (2007). Mechanisms of silicon - mediated alleviation of abiotic stresses in higher plants. A review. Environmental Pollution , 147,422-428.

Lima Filho, O.F. de and Abdalla, Al . (2008). Production of foliar phenolics and condensed tannins in pigeaon pea and Leucaena supplemented with silicon, Silicon in Agriculture Conference. South Africa, 63.

Lima Filho,O.F.; Tsia, S.M. ; Mercante, F.M. and Figueiredo , L.A. (2005) . The effect of silicon on nodulation and nitrogen fixation of soybean and bean under hydroponic conditions III. Silicon in Agriculture Conference. Uberlandia/ MG- Brazil.

Lee, K.S. ;Ahn, S.B.; Rhee ,G.S.; Yeon B.Y. and Park , J.K. (1985) . Studies of silicon application to nursery beds on rice seedling growth.Res.Rep. Rural Dev. Admin Plant Environ, Mycol. Farm Product Utilization. Korea Republic 27,1,23-27 . [In Korean: Rice Abstr . 10,2502. 1987]

Ma, J.F. ;Miyake ,Y. and Takahashi, E. (2001). Silicon as a beneficial element for crop plants Studies in Plant Science 8,17-39.

Ma, G.F. and Yamaji ,N. (2006). Silicon uptake and accumulation in higher plants. Review. Trends in Plant Science ,11,8,329-397. 
Matichenkov, V.V. and Calvert, D.V. (2002) . Silicon as a beneficial element for sugarcane .Journal American Society of Sugarcane Technologists $22,21-30$.

Matichenkov, V. V. and Kosobrukhov A.A. (2004). Si effect on the plant resistance to salt toxicity .ISCO 2004. $13^{\text {th }}$ International Soil Conservation Organisation Conference-Brisbane.

Metzner ,H.; Rau,H. and Senger ,H. (1965). Unter suchungen Zur synchronisier barkeit einzelner pigment . Managol Mutanent Van chlorella . Plants 65,186- 192.

Nwugo ,C. and Huerta ,A.J. (2008) .Effects of silicon nutrition on cadmium uptake, growth and photosynthesis of rice plants exposed to low - level cadmium. Plant and Soil 311, 1-2, 73-86.

Renault ,S. ;Croser, C. , Franklin ,J.A. ;ZwiaZek, J.J. and Mackinnon, M. (2001). Effect of Consolidated tailings water on red- osier dogwood (Conu stolonifera michx ) seedlings. Environmental Pollution 113, 27- 33.

Rodrigues, F.A.; Jurick, W.M.; Datnoff, L.E.; Rollins, J. A. and Jones, J.B. (2005). Silicon influences cytological events in compatible and incompatible riceMagnaporthe grisea interaction. III Silicon in Agriculture conference,22-26 October Uberlandia / M.G- Brazil.

Savant , N.K. and Sawant , A.S. (1995). Nutrient composition of rice seedlings as influenced by rice hull ash application to seedbed . Oryza.43,62-71.

Savant, N.K. ; Synder, G.H . and Datnoff , L.E. (1997). Silicon management and sustainable rice production . Adv . Agron. 58 , 151-199.

Savvas, D.; Giotis , D.; Chatzieustratiou , E.; Bakea , M. and Patakioutas , G. (2009). Silicon supply in soiless cultivations of zucchini alleviates stress induced by salinity and powdery mildew infections. Environmental and Experimental Botany 65, 11-17.

Stegemann , H. (1979). Electrophoresis and Focusing in slabs using the PANTA - PHOR apparatus for analytical and preparative separation in Gels (polyacrylamide, agarose, starch sephadex (etc) suppl. Inst - Biochem messeweg 11, D-3300, Braunschweig , Germany, p.11.

Tale Ahmed , S. and Haddad , R. (2008) .Study of silicon effects on wheat cultivars under drought stress. Silicon in Agriculture Conference. South Africa,99.

Tesfagiorgis , H.B.; Liang,M.D. and Morris, M.J. (2008) Uptake and distribution of silicon on zucchini and zinnia and its interaction with other elements. Silicon in Agriculture Conference. South Africa,101.

Wendel , J.F. and Weeden , N.F. (1989) . Visualization and interpretation of plant isozyme. In Plant Bioloker , Sokis, D.E and Solds, S.D. (eds) Chaperon and Hull Publishers, London, p.18.

Williams , S. and Twine, M. (1960). Flame photometric method for sodium, potassium and calcium . In Peach, K . and Tracey, M . V . ed; Modern Methods of Plants Analysis, Vol.5 p.3-5 Springer - Verlag , Berlin.

Yang , Y. ; Li,J.; Shi,H.;Ke,Y.;Yuan , J. and Tang, Z. (2008). Alleviation of silicon on low -P stressed maize(Zea mays L) seedlings under hydroponic culture conditions . Word Journal of Agricultural Sciences 4,2,168-172.

Zhu , Z.;Wei ,G. ;Li, J. ; Qian , Q. and Yu , J . (2004). Silicon alleviates salt stress and increases antioxidant enzyme activity in leaves of salt - stressed cucumber (Cucumis sativus L) , Plant Sci. , 167,527-533. 